\title{
Computational simulations of the cable-stayed bridge over the Vistula River in Krakow
}

\author{
Michat Topolewicz ${ }^{1, *}$, and Krzysztof Topolewic $z^{2}$ \\ ${ }^{1}$ Gdańsk University of Technology, Faculty of Civil and Environmental Engineering, \\ Narutowicza 11/12, 80-233 Gdańsk, Poland \\ ${ }^{2}$ TOP PROJEKT
}

\begin{abstract}
This article presents the execution method of a cable stayed bridge over the Vistula River in Krakow together with FEM-based computational simulations carried out during the design process. The performed calculations concern the global system in its final stage and in the construction stages as well as local analysis of construction details. The obtained results made it possible to work out efficient solutions that contribute to a significant reduction of the project cost and execution time shortening.
\end{abstract}

\section{Introduction}

The cable-stayed bridge across the Vistula River in Krakow, designated as MD-7 [1], is located along the important expressway S7. The main span, $200,0 \mathrm{~m}$ long is one of the longest spans in Poland. The main contractor STRABAG chose the TOP PROJEKT team led by an experienced bridge designer Krzysztof Topolewicz to optimize the execution design. The aim of the optimization was to reduce the overall investment costs adjusted to the available technological solutions and the completion date.

The FEM computational analysis was performed during the design process to prove the fulfillment of a load capacity condition in final state, construction stages and to check the critical details of the superstructure. The experience gained in the course if analysis, similarly to the cases presented in [2-8], indicates the importance of the method to computationally simulate the structural behaviour. A key problem is the selection of an appropriate theoretical description due to an analysed issue in order to yield correct conclusions. A detailed analysis of construction stages contributes to a significant reduction of costs and time, additionally, it leads to effective structural solutions.

\section{Description of the bridge}

The MD-7 bridge consists of two parallel structures for two roadways of the S7 expressway (Fig. 1). Each structure consists of three superstructures: two three-span prestressed concrete box girder access viaducts over the floodplain and the main bridge with a cablestayed span. The total length of the bridge is $706,0 \mathrm{~m}$ a $390 \mathrm{~m}$ section $(45+50+200+50+45)$ is the main cable-stayed structure.

\footnotetext{
* Corresponding author: michal.topolewicz@pg.edu.pl
} 


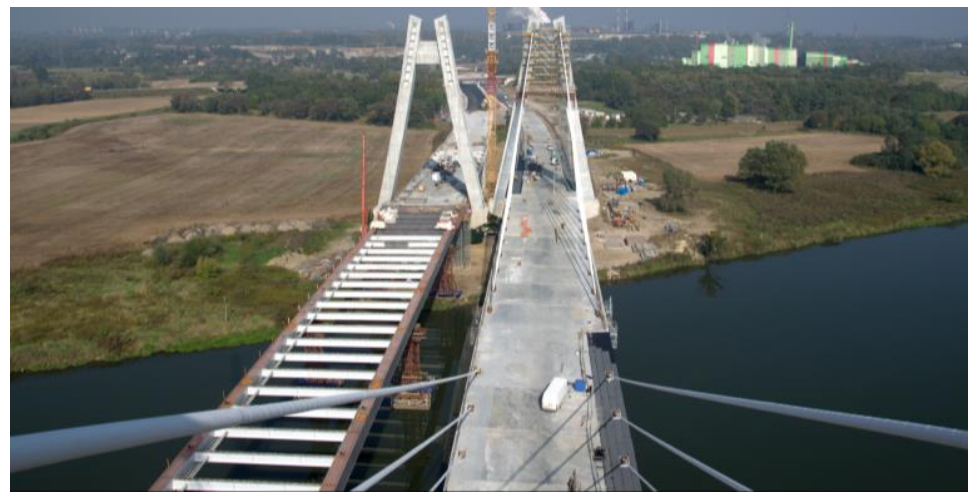

Fig. 1. The bridge MD-7 under construction.

The main superstructure consists of two subsections of different cross-section. In the main span a ladder deck steel-concrete composite section occurs with two steel box girders, I-beam cross girders and a reinforced concrete slab $280 \mathrm{~mm}$ thick (Fig. 2). In the access spans both longitudinal and cross girders are made of prestressed concrete. This distinction adopted at the optimization stage brought several economic and structural benefits such as: reduction of the span weight, elimination of negative reaction forces on the ballast spans supports, additionally it allowed for parallel execution of a number of elements to accelerate the working schedule. A normal C50/60 class concrete was used to cast the deck slab in the main span, however the possibility of using light-weight concrete was analysed in other bridges in future as part of the academic work [9].

The deck is suspended from two-armed $66,0 \mathrm{~m}$ height towers by parallel strand cablestays. The active cable anchorages are located under the deck in both concrete and steel sections. The strands pass continuously through the saddles on the pylons. The number of strands in the cable-stays varies from 24 to 37 . The spacing of the anchorages in the deck is $10.0 \mathrm{~m}$.

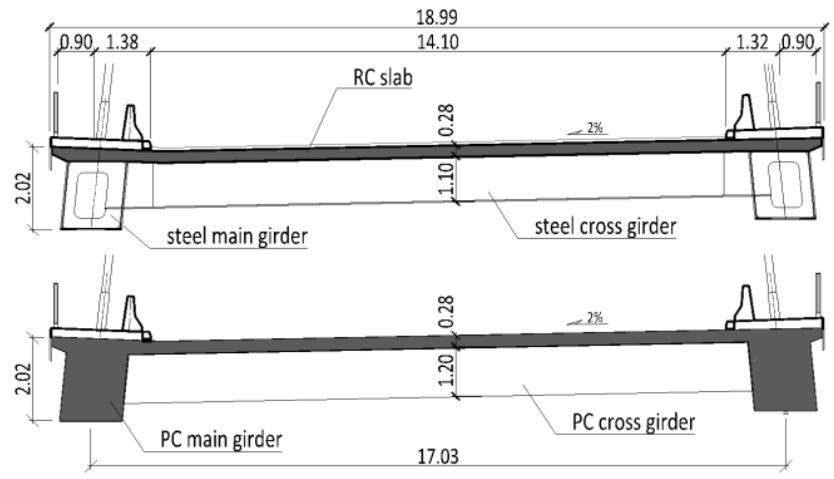

Fig. 2. Cross section of the main span (steel-concrete) and of the access span (prestressed concrete).

The bridge bearing system is a floating system with virtual fixed point in the middle of the main span. The deck is supported on the towers by neoprene bearings of relatively low rigidity, the supports on other piers are pot bearings. The function of a longitudinal fixed bearing is taken by cable-stays.

There are four concrete pylons (two for each structure). Each pylon includes a footing, a cylindrical column, a transverse girder, two arms and top bracing deep beam. The cylindrical column diameter is $9 \mathrm{~m}$, its height is $4,8 \mathrm{~m}$. A transverse girder of trapezoidal shape, located directly on the column, is the most massive element of the bridge. It is post- 
tensioned with 24 19-strand cables. The pylon arm is a hollow reinforced concrete section up to $30 \mathrm{~m}$ height above the deck. The higher part is a solid section with cable-stay saddles installed inside. Each saddle is adjusted in space to the angle of cable-stays.

The foundations of the four pylons have been designed as square footings, their dimensions are $20,0 \times 20,0 \times 4,1 \mathrm{~m}$. Their bearing capacity is ensured by precast reinforced concrete piles of a $40 \times 40 \mathrm{~cm}$ section. The length of piles is $9,0 \mathrm{~m}$, their bases are embedded in a layer of compacted fine sand.

The bridge has been designed according to both Eurocodes and former Polish Standards (although the investor only required the latter). The bridge was tested under the load model LM1 $(\alpha=1,0)$ and the A-class bridge load model from PN-S. The fatigue strength check was based on the FLM3 model.

\section{Structural analysis}

\subsection{Global static analysis}

Both static analysis and dimensioning were performed in SOFiSTiK the FEM-based computational environment [10-12]. The global three-dimensional computational model of the bridge (Fig. 3) was made of: 3890 Timoshenko beam elements with 6 nodal degrees of freedom (main girders, cross beams, piers, pylons), 28480 four-node Mindlin-Reissner shell elements (deck slab) and 64 cable elements (cable-stays). The number of nodes was 51989 , the number of dofs was 126484 . The support conditions were defined in the form of elastic springs with appropriate stiffness, assessed upon geotechnical calculation.

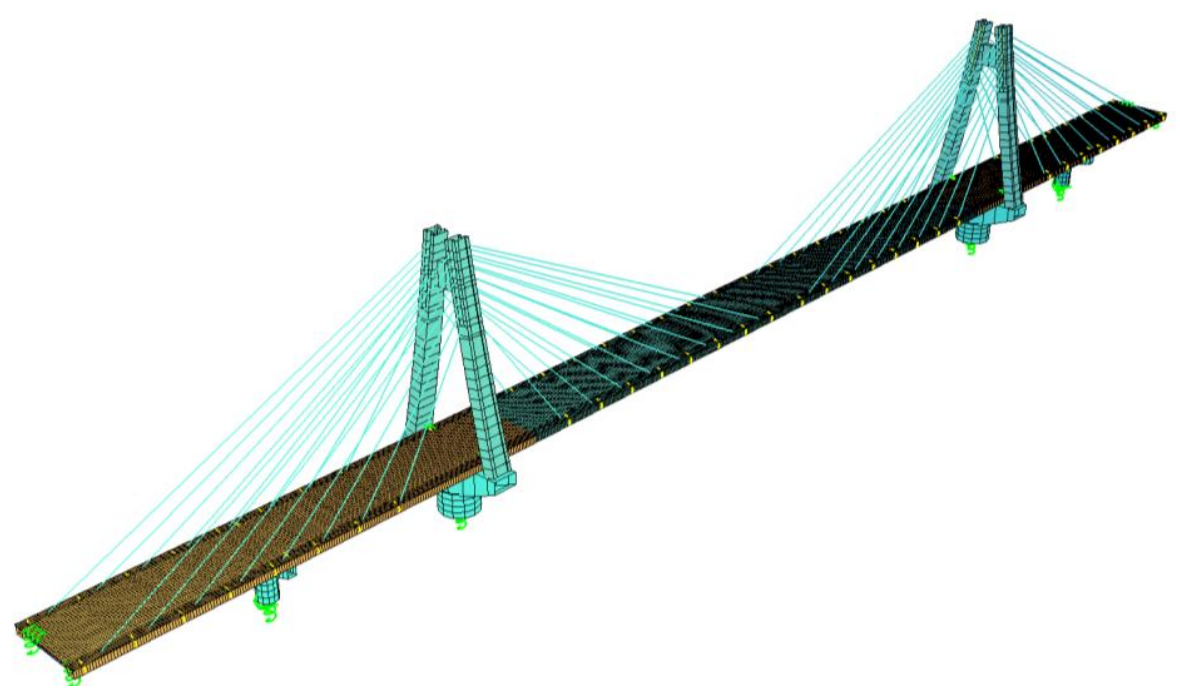

Fig. 3. Visualization of the global finite element model of the MD-7 bridge.

The global model was applied for static calculations in the final stage and in the construction stages. It was used to determine tensile forces introduced to cable-stays and deck displacements in the execution stages.

Additionally, local partial models were created to analyse structural details, e.g. cablestay anchorages, post-tensioning cable anchorages, joints of steel and concrete sections, precast deck planks. A detailed model of a pylon was analyzed to investigate the erection process too. 


\subsection{Construction stage analysis}

The concrete towers were erected using sliding scaffolding. The erection process was analysed by means of a detailed model incorporating shell finite elements (Fig. 4).

The construction principle was analogous to the cantilever method. Each segment introduced a load on the previous ones. The inclination of the pylon arms caused their bending. In order to minimize additional bending moments in the arms temporary struts were applied, but nevertheless it was necessary to calculate the arm deflection to obtain the designed geometry, introducing a precamber. The influence of concrete age on its elastic modulus was included in the analysis due to time of execution of a single segment lower than 3 days.

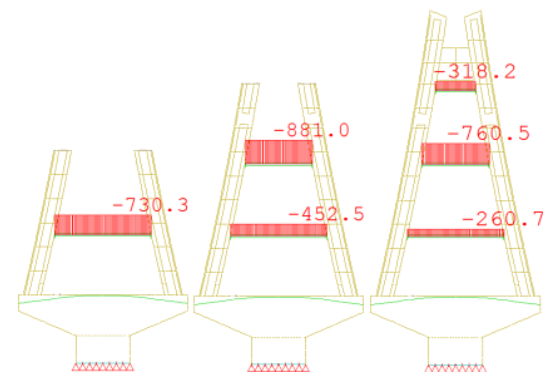

Fig. 4. Forces in temporary struts during in different construction stages of pylon.

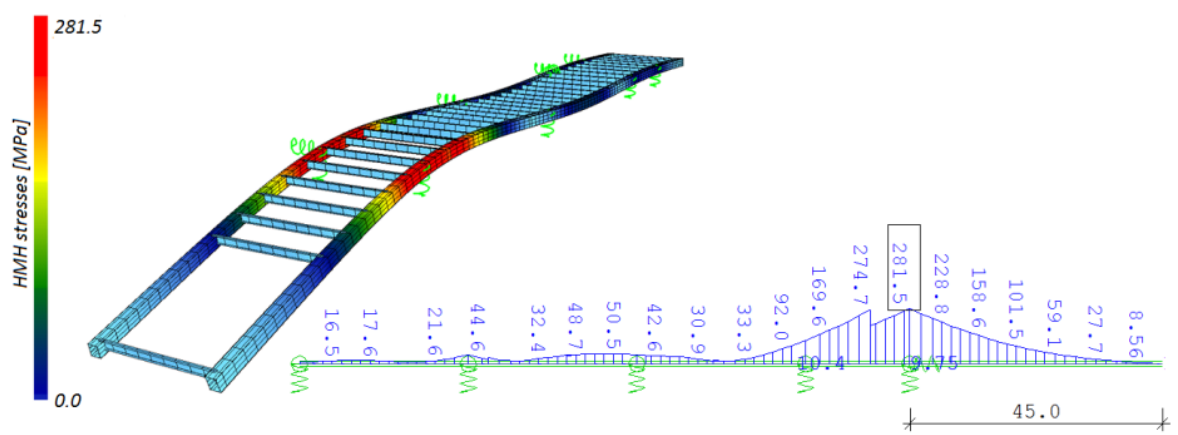

Fig. 5. Computational model for analysis of incremental launching of steel structure and a graph of HMH stresses in a steel box girder at the maximum cantilever overhang length.

The main span of the bridge is a steel-concrete composite ladder deck structure. The execution of steel girders was performed by means of incremental launching. In order to analyse it during this process the steel structure was isolated from the global bridge model and analysed with variable support conditions encountered during the launching (Fig. 5).

In this case, the concrete span had to be checked as well, because the assembly of steel segments was carried out on an access span already built. The steel structure weight and the working equipment load, e.g. cranes were to be considered in the global bridge analysis.

The access spans were erected on stationary scaffolds, span-by-span with the use of additional temporary supports. After their execution, on the deck of the bridge on one of the banks the steel structure was assembled and launched over the river. The incremental launching was carried out with the help of four temporary supports in the river. After joining the concrete and steel sections the process of concreting the deck slab in the main span was started. It was executed together with stay assembling and tensioning. The introduction tensile forces into the cable-stays caused progressive lifting of the deck from temporary supports. As a result, the performed calculations were non-linear due to 
boundary non-linearity. There was also geometrical non-linearity caused by cable sag due to its low tensile forces during construction stages.
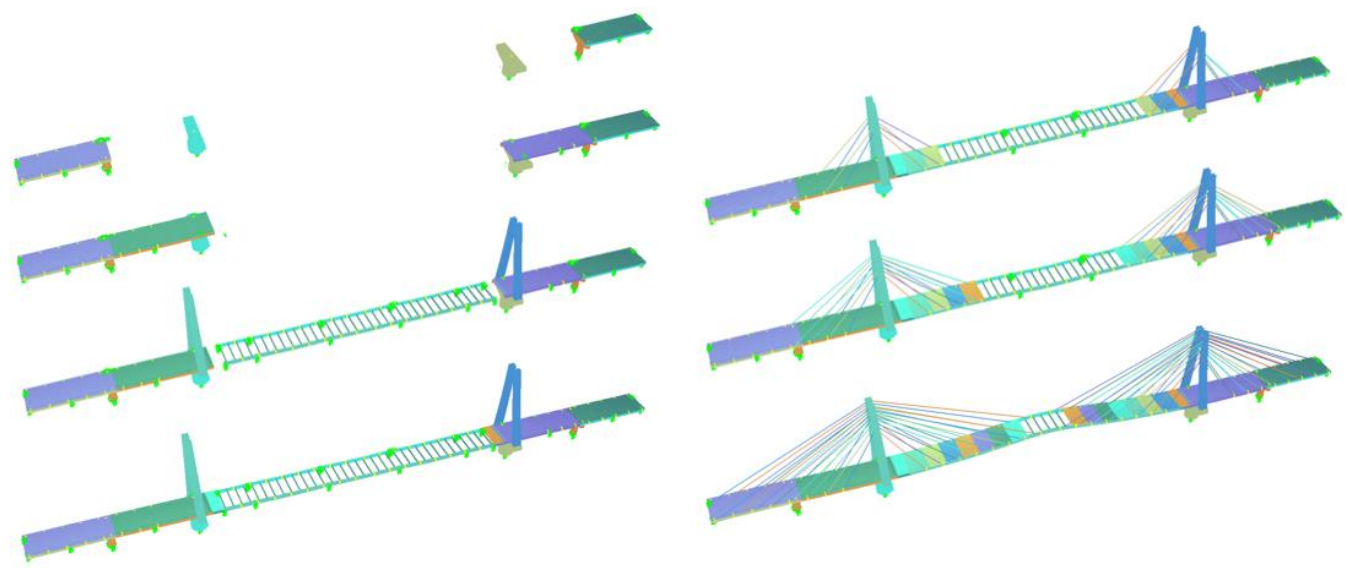

Fig. 6. Several of the modelled construction stages.

All erection stages have been considered in the global bridge finite element model (Fig. 6). The main advantage of a complex modelling, introducing shell elements for a deck slab is inherent consideration of a shear lag effect. Thus there is no need to use the effective width approach. This is important, because in every construction stage the effective width of a slab may be variable, to act strongly on the accuracy of the detection of displacements and stress distribution in the deck slab, especially when the main girders are located at the cross section edges. In this case it should be noted that the anchorage zone of cable-stays is not terminated in the steel girder, but it extends to the slab where tensile stresses are introduced due to point load character, to be considered during the slab reinforcement design

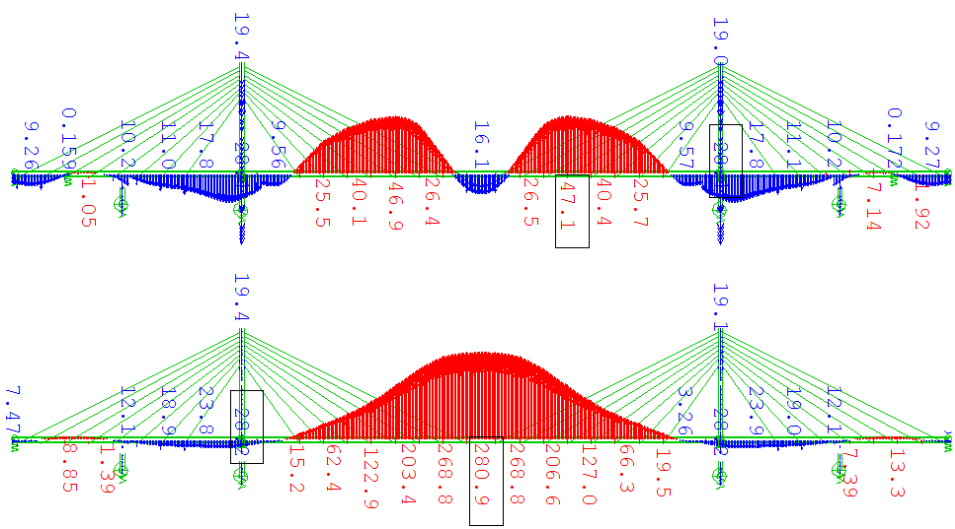

Fig. 7. Displacements of the deck before and after tensioning of cable stay no 7.

In the middle of the main span the vertical displacement amplitudes between the stage of casting concrete slab $10 \mathrm{~m}$ segment and tensioning of a cable-stay were approximately $300 \mathrm{~mm}$ (Fig. 7). Geodetic measurements were carried out in real-time during execution. They allowed to check the structural geometry, taking into account temperature influence. The measured deviations from the theoretical altitude in construction stages did not exceed $40 \mathrm{~mm}$ and final deviations after closing the execution works were less than $20 \mathrm{~mm}$. 


\subsection{Analysis of construction details}

\subsubsection{Joint between steel and concrete section}

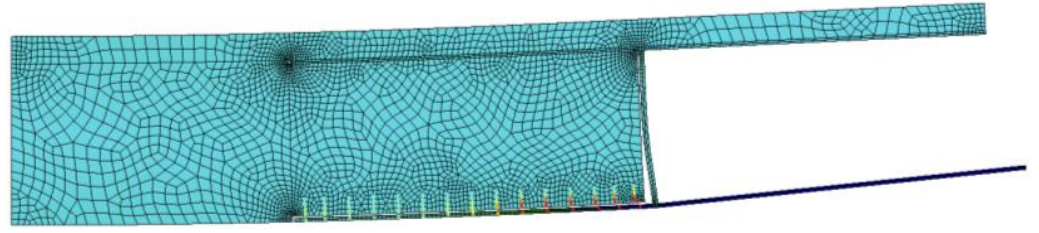

Fig. 8. Local plane model of joint between steel and concrete section.

A joint between steel and concrete sections was analysed in a plane stress model, focusing on shear studs flexibility. There are dead anchorages of post-tensioning cables located in the concrete part. Each strand was formed into an "onion" to smoothly develop the prestressing force into a section. In the plane model (Fig. 8) the prestressing force has been modelled as a surface load.

\subsubsection{Cable-stays anchorage}

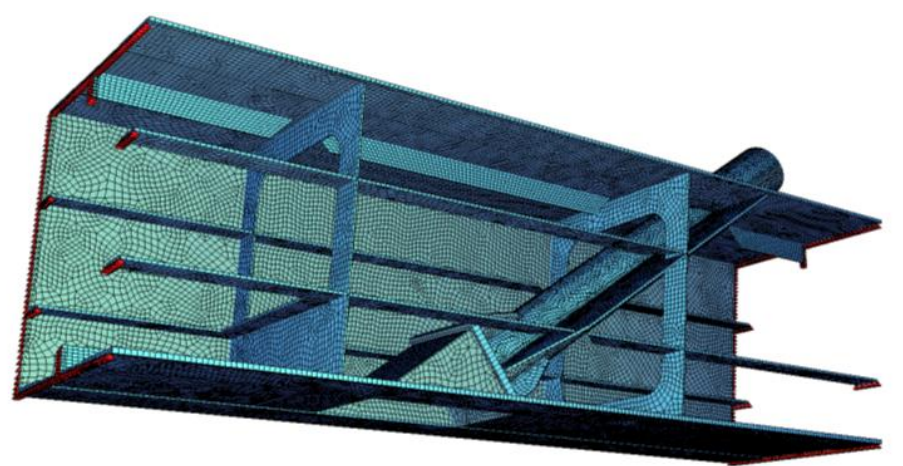

Fig. 9. Spatial local FEM model of cable-stay anchorage in steel structure (one web removed to improve visibility).

The analytical details, e.g. the anchorage of cable-stays in steel structure form a challenge to the designer. It is necessary to combine all design aspects, like ensuring load-bearing capacity, durability and maintenance. In order to meet all of these requirements, detailed models were created of cable-stays anchorages in steel structure (Fig. 9).

In the concrete section the anchorages of cable-stays have to be designed individually due to lack of systemic reinforcement solutions available, the aim was to avoid the problems similar to [13]. A confined concrete theory was applied to design a spiral reinforcement [14]. All anchorages were dimensioned for the breaking load of tendons, in accordance, assuming that the anchorage should not be the weakest element of a cable-stay. In the case of fatigue strength anchorages are designed to last longer than the cable itself. In order to conduct the fatigue checks in those untypical elements the hot-spot method was applied [15].

\subsubsection{Reinforced concrete precast formwork planks}

The use of precast formwork planks allows to efficiently design the steel structure cross girder. The planks were both slab formwork and lateral-torsional bracing of the cross beam 
top flange. The use of planks accelerated the execution time of the slab too. A single segment of $10,0 \mathrm{~m}$ length was executed in less than 3 days. The precast filigree planks had a record breaking length of $5,0 \mathrm{~m}$. For this reason, a detailed finite element model was created. The plank was modelled by four-node shell elements, the rebars were beam elements. The concrete stiffness in the longitudinal direction was reduced due to cracking. Geometry of rebars was defined by means of imperfections corresponding to their buckling modes resulting from the eigenproblem of stability. The accidental state was also investigated, detecting a single welded joint of the truss and a top rebar damaged.

Before applying the precast planks in the construction, a test load was carried out. It confirmed bearing capacity calculated previously.

\section{Concluding remarks}

The design and construction project of the bridge MD7 was an interesting challenge to the entire design and executive team. The use of advanced finite element method modelling for global and local design cases allowed to obtain an efficient constriction and a precise assessment of displacements and forces in cable-stays. Thus it was made possible to execute the bridge on time encountering no major problems.

The applied FEM-based solutions are particularly useful in the case of non-typical structures with unusual solutions, not covered by any guidelines. A detailed local analysis allows to design efficient solutions characterized by high durability. In the case of MD7 bridge, measurements made during construction, acceptance tests in the form of trial load test similar to [16-17] and the first results read from the installed monitoring system resembling [18-26] confirm the assumptions made in structural design and modelling.

However it should be noted that the analysis complexity also leads to difficulties at the stage of interpreting the results and verifying the correctness of the assumed model. The experience in the design and modelling of other large and smaller bridge structures is invaluable while analysing a complex bridge.

\section{References}

1. K. Topolewicz, Executive detailed design (replacement design) of MD-7 bridge, (TOP PROJEKT, STRABAG 2015)

2. M. Miśkiewicz, Ł. Pyrzowski, K. Wilde, J. Chróścielewski: Numerical analysis and in situ tests of the Grot Rowecki Bridge in Warsaw. Adv. in Mech., 405-408 (2016)

3. J. Chróścielewski, M. Miśkiewicz, Ł. Pyrzowski, K. Wilde, Assessment of tensile forces in Sopot Forest Opera membrane by in situ measurements and iterative numerical strategy for inverse problem, Shell Str.: Th. \& Appl., 3, 499-502 (2014)

4. M. Miśkiewicz, K. Daszkiewicz, T. Ferenc, W. Witkowski, J. Chróścielewski, Experimental tests and numerical simulations of full scale composite sandwich segment of a foot-and cycle- bridge, Adv. in Mech, $401-404$ (2016)

5. Ł. Pyrzowski, M. Miśkiewicz, J. Chróścielewski, "The effect of fishing basin construction on the behavior of a footbridge over the port channel," PMR 2017 S1 (93), 24, 182-187 (2017)

6. M. Miśkiewicz, Ł. Pyrzowski, Influence of an applied bearing system on behavior of multi-span footbridge, Shell Str.: Th. \& Appl., 4, 433-436 (2018)

7. J. Chróścielewski, M. Miśkiewicz, Ł. Pyrzowski, B. Sobczyk, K. Wilde, A novel sandwich footbridge - Practical application of laminated composites in bridge design and in situ measurements of static response, Comp. Eng., 126, 153-161 (2017) 
8. A. Mariak, M. Miśkiewicz, B. Meronk, Ł. Pyrzowski, K. Wilde, Reference FEM model for SHM system of cable-stayed bridge in Rzeszów, Adv. in Mech. - Kleiber et al. (Eds), 383-387, (2016),

9. M. Kurpińska, T. Ferenc: Application of lightweight cement composite with foamed glass aggregate in shell structures, Shell Str.: Th. \& Appl., 4, 549-552 (2018)

10. J. Chróścielewski, W. Witkowski, Four-node semi-EAS element in six-field nonlinear theory of shells. Inter. J. for Num. Meth. In Eng., 68, 1137-1179 (2006)

11. J. Chroscielewski, A. Sabik, B. Sobczyk, et al. Nonlinear FEM 2D failure onset prediction of composite shells based on 6-parameter shell theory, Thin-walled structures, 105, 207-219

12. L. Mazurkiewicz, J. Malachowski, P. Baranowski, et al., Comparison of numerical testing methods in terms of impulse loading applied to structural elements, J. of Th. and Appl. Mech., 51 ,615-625 (2013)

13. J. Chróścielewski, M. Miśkiewicz, Ł. Pyrzowski, B. Sobczyk, Analysis of damage in the zone of tensioning cables anchorages of a bridge superstructure, using CDP ABAQUS material model, Arch. of Civil Eng., 63, 85-97 (2017)

14. J.B Mander, M. J. N. Priestley, R. Park, Theoretical stress-strain model for confined concrete. J. of Str. Eng., 114, 1804-1825 (1998)

15. A. Nussbaumer, L. Borges, L. Davaine, Fatigue design of steel and composite structures (Wiley \& Sons, 2012)

16. M. Miśkiewicz, K. Makowska, Displacement measurements during load testing of railway arch bridge, SGEM2017, 17, 257-264 (2017)

17. I-K. Fang, C-R. Chen, I-S. Chang, Field Static Load Test on Kao-Ping-Hsi CableStayed Bridge, J. of Bridge Eng., 9, 531-540 (2004)

18. A. Janowski, K. Nagrodzka-Godycka, J. Szulwic, P. Ziolkowski, Remote sensing and photogrammetry techniques in diagnostics of concrete structures, Comput. Concr., 18, 405-420 (2016)

19. M. Miśkiewicz, B. Meronk, T. Brzozowski, K. Wilde, Monitoring system of the road embankment, Baltic J. of Roads and Bridge Eng., 12, 218-224 (2018)

20. M. Miśkiewicz, O. Mitrosz, T. Brzozowski Preliminary field tests and long-term monitoring as a method of design risk mitigation: a case study of Gdańsk Deepwater Container Terminal, PMR 24: 106-114 (2017)

21. M. Miśkiewicz, Ł. Pyrzowski, J. Chróścielewski, K. Wilde, Structural Health Monitoring of Composite Shell Footbridge for Its Design Validation, BGC Geomatics 228-233 (2016)

22. M. Miskiewicz, L. Pyrzowski, K. Wilde, Structural Health Monitoring System for Suspension Footbridge, BGC Geomatics, 321-325 (2017)

23. K. Wilde, M. Miśkiewicz, J. Chróścielewski, SHM System of the Roof Structure of Sports Arena „Olivia”. Stru. Health Mon. 2013, 2, 1745-1752, (2013)

24. W. Kaminski., K. Makowska, M. Miśkiewicz, J. Szulwic, K. Wilde, System of monitoring of the Forest Opera in Sopot structure and roofing, SGEM 2015, 2, 471-482 (2015)

25. J. Hou, L. Jankowski, J. Ou, An online substructure identification method for local structural health monitoring, Smart Mat. and Str., 22 (2013)

26. G. Suwala, L. Jankowski, A model-free method for identification of mass modifications, Str. Control and Health Mon., 19, 216-230 (2012) 